\title{
Paediatric cyclical Cushing's disease due to corticotroph cell hyperplasia
}

\author{
E. Noctor ${ }^{1}$, S. Gupta ${ }^{1}$, T. Brown ${ }^{1}$, M. Farrell ${ }^{2}$, M. Javadpour ${ }^{3}$, C. Costigan ${ }^{4}$ and A. Agha ${ }^{1 *}$
}

\begin{abstract}
Background: Cushing's disease is very rare in the paediatric population. Although uncommon, corticotroph hyperplasia causing Cushing's syndrome has been described in the adult population, but appears to be extremely rare in children. Likewise, cyclical cortisol hypersecretion, while accounting for $15 \%$ of adult cases of Cushing's disease, has only rarely been described in the paediatric population. Here, we describe a very rare case of a 13-year old boy with cyclical cortisol hypersecretion secondary to corticotroph cell hyperplasia.
\end{abstract}

Case presentation: The case is that of a 13-year old boy, presenting with a long history of symptoms and signs suggestive of hypercortisolism, who was found to have cyclical ACTH-dependent hypercortisolism following dynamic pituitary testing and serial late-night salivary cortisol measurements. The patient underwent endoscopic transsphenoidal resection of the pituitary. Early surgical remission was confirmed by undetectable post-operative morning plasma cortisol levels. Histology and immunocytochemistry of the resected pituitary tissue showed extensive corticotroph cell hyperplasia.

Conclusion: This report describes a rare case of cyclical Cushing's disease secondary to corticotroph hyperplasia in a paediatric patient. This highlights the challenging and varied nature of Cushing's disease and its diagnosis, and the need to keep a differential diagnosis in mind during the diagnostic process.

Keywords: Corticotroph hyperplasia, Cyclical hypercortisolism, Paediatric Cushing's

\section{Background}

Cushing's disease is rare in the paediatric population, and is invariably due to a corticotroph adenoma, usually a microadenoma [1]. Corticotroph hyperplasia as a cause of Cushing's syndrome, although uncommon, has been described in the adult population. However, this appears to be extremely rare in children. Also, cyclical cortisol hypersecretion, while accounting for $15 \%$ of adult cases of Cushing's disease [2], has very rarely been described in the paediatric population [3]. Here we describe the case of a 13-year old boy with cyclical cortisol hypersecretion secondary to corticotroph cell hyperplasia, and review the relevant literature with regard to paediatric Cushing's disease.

\section{Case presentation}

A 13 year-old boy was referred to the endocrine service for evaluation. Our patient and his family described a

\footnotetext{
* Correspondence: amaragha@beaumont.ie

'Department of Endocrinology and Neurosurgery, Beaumont Hospital,

Beaumont Road, Dublin 9, Ireland

Full list of author information is available at the end of the article
}

history of early adrenarche aged 5 , and, beginning at age 9, the gradual onset of marked weight gain and development of a rounded, plethoric facies. In retrospect, proximal muscle weakness was also felt to have begun at this time. He presented to his primary care practitioner at the age of 12, and was referred on to a paediatric endocrinology tertiary referral centre for further assessment.

At initial assessment, weight was $95.9 \mathrm{~kg}$ (above the $99.6^{\text {th }}$ centile) with a height of $147 \mathrm{~cm}$ (between $10-25^{\text {th }}$ centile). He had markedly Cushingoid facies, an interscapular fat pad, and increased abdominal girth with striae, with objective evidence of proximal myopathy (Fig. 1). Blood pressure was normal.

A $1 \mathrm{mg}$ overnight dexamethasone suppression revealed a post-suppression cortisol value of $258 \mathrm{nmol} / \mathrm{L}$ (normal $<50 \mathrm{nmol} / \mathrm{l}$ ). Twenty-four hour urinary free cortisol was markedly elevated at $987 \mathrm{nmol} / 24 \mathrm{~h}$ (reference range $0-83 \mathrm{nmol} / 24 \mathrm{~h}$ ). Given the characteristic clinical picture, and 2 positive screening tests, a diagnosis of Cushing's syndrome was made. His ACTH level was not suppressed, consistent with ACTH-dependent Cushing's 


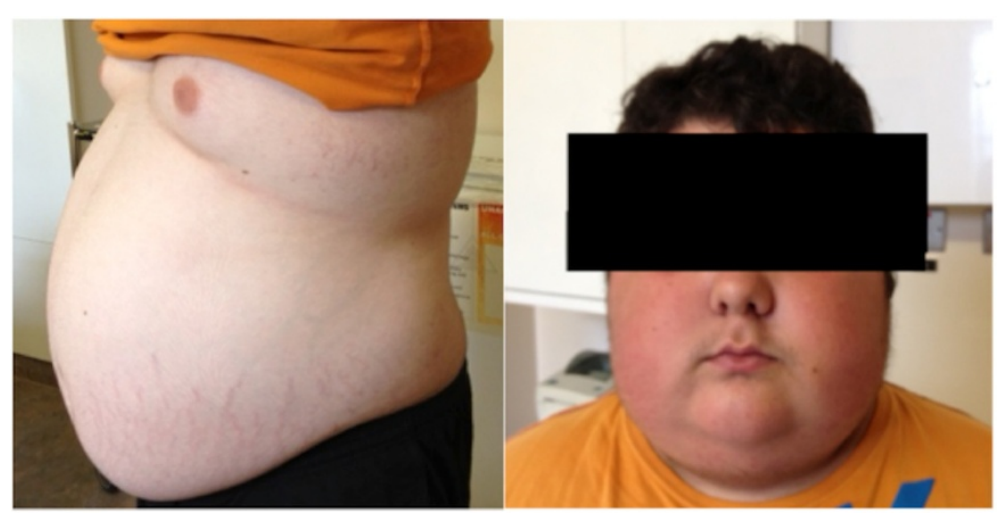

Fig 1 Pictures taken the week prior to surgery, demonstrating increased abdominal circumference, striae, and Cushingoid facies

syndrome. A peripheral human corticotropin-releasing hormone $(\mathrm{CRH})$ test showed a greater than $50 \%$ rise in ACTH after $15 \mathrm{~min},(60.1 \mathrm{pg} / \mathrm{ml}$ at 0 mins rising to $104 \mathrm{pg} / \mathrm{ml}$ at $15 \mathrm{mins}$ ), along with an almost $50 \%$ rise in cortisol (756 to $1126 \mathrm{nmol} / \mathrm{L}$ ). This is highly characteristic of pituitary dependent Cushing's syndrome (Cushing's disease) [4]. A contrast-enhanced dynamic pituitary MRI scan was performed, and interpreted by a specialist pituitary neuroradiologist. This revealed a radiologically normal pituitary gland.

On questioning, the patient reported fluctuations in his symptoms with some days feeling more symptomatic than others. To assess for the possibility of cyclical oversecretion of ACTH/cortisol, we performed serial salivary cortisol measurement, which has been shown to have similar sensitivity to urine sampling for the detection of cyclical hypercortisolism [5] (the patient was not taking any medication that could interfere with the result). This showed several peaks and two normal value troughs (Fig 2), consistent with cyclical Cushing's disease.

To confirm the diagnosis of pituitary dependant Cushing's syndrome, inferior petrosal sinus sampling (IPSS) was performed under general anaesthesia with samples obtained at baseline, and then at different time points following $\mathrm{CRH}$ administration. Unfortunately, the first test showed no central to peripheral gradient as it was done on a day when the disease was not active. A repeat IPSS was subsequently performed on a morning when the disease was active - an early morning cortisol on the morning of the procedure was $845 \mathrm{nmol} / \mathrm{l}$, confirming hypercortisolaemia. This second IPSS showed a marked central to peripheral gradient (Left petrosal ACTH concentration at $0 \mathrm{mins}>2100 \mathrm{pg} / \mathrm{ml}$, left peripheral ACTH concentration $167 \mathrm{pg} / \mathrm{ml}$ at $0 \mathrm{mins}$ ). A marked left to right gradient was also evident (Results summarised in Table 1). This confirmed that the patient had Cushing's disease.

The patient underwent endoscopic transsphenoidal exploration of the pituitary by our dedicated pituitary surgeon. This revealed abnormal soft tissue in the midline and to the left of the pituitary fossa, all of which was macroscopically removed at surgery. Aside from transient diabetes insipidus, our patient's post-operative course was unremarkable. Several serial morning (8 am) serum cortisol levels were all less than $28 \mathrm{nmol} / \mathrm{l}$ confirming early remission (defined as post-operative cortisol values $<50 \mathrm{nmol} / \mathrm{L}$ ). The patient was discharged on hydrocortisone $10 \mathrm{mgs}$ twice daily.

\section{Histology and immunostaining}

The excised surgical specimen consisted of adenohypophysis characterised by an admixture of cells arranged into nests (Fig 3). Cells with eosinophilic cytoplasm and clear cytoplasm, together with occasional cells having basophilic cytoplasm were all present. Immunocytochemistry demonstrated immunoreactivity for TSH, FSH, LH, and prolactin. Additionally there was extensive widespread ACTH

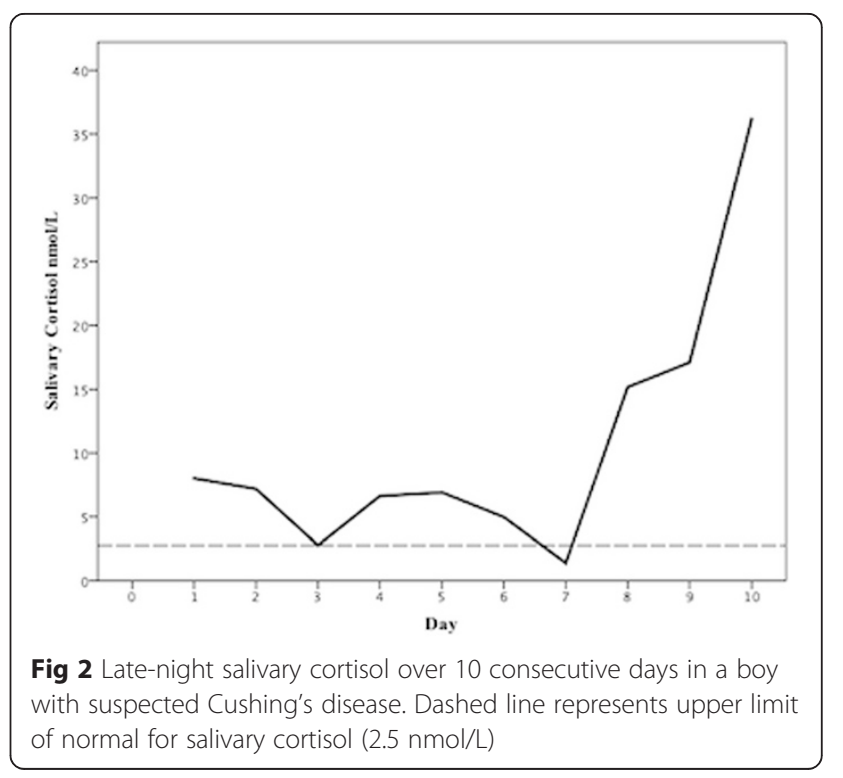


Table 1 Summary of dynamic tests

\begin{tabular}{|c|c|c|}
\hline Test & Result & Interpretation \\
\hline \multirow[t]{2}{*}{$\begin{array}{l}1 \mathrm{mg} \text { overnight } \\
\text { DST }\end{array}$} & $\begin{array}{l}\text { Morning cortisol } \\
258 \mathrm{nmol} / \mathrm{L}\end{array}$ & \multirow[t]{2}{*}{$\begin{array}{l}\text { Failure to suppress } \\
\text { cortisol secretion }\end{array}$} \\
\hline & $\begin{array}{l}\text { (normal suppression } \\
<50 \mathrm{nmol} / \mathrm{L} \text { ) }\end{array}$ & \\
\hline \multirow[t]{2}{*}{$24 \mathrm{~h}$ UFC } & $987 \mathrm{nmol} / \mathrm{L}$ & \multirow{2}{*}{$\begin{array}{l}\text { Values greater than } 3 \text { times } \\
\text { ULN are highly suggestive of } \\
\text { Cushing's syndrome }\end{array}$} \\
\hline & (Ref. 0-83 nmol/L) & \\
\hline \multirow[t]{4}{*}{$\mathrm{CRH}$ test } & $\begin{array}{l}\text { ACTH } 0 \text { mins } \\
60 \mathrm{pg} / \mathrm{ml}\end{array}$ & \multirow[t]{4}{*}{$\begin{array}{l}\text { Greater than } 50 \% \text { rise in ACTH, } \\
\text { suggestive of Cushing's syndrome }\end{array}$} \\
\hline & $\begin{array}{l}\text { Cortisol } 0 \text { mins } \\
756 \mathrm{nmol} / \mathrm{L}\end{array}$ & \\
\hline & $\begin{array}{l}\text { ACTH } 15 \text { mins } \\
104 \mathrm{pg} / \mathrm{ml}\end{array}$ & \\
\hline & $\begin{array}{l}\text { Cortisol } 15 \text { mins } \\
1126 \mathrm{nmol} / \mathrm{L}\end{array}$ & \\
\hline \multirow[t]{4}{*}{$\begin{array}{l}\text { IPSS (CRH } \\
\text { augmented) }\end{array}$} & $\begin{array}{l}\text { ACTH values } \\
5 \text { mins post } C R H\end{array}$ & \multirow[t]{4}{*}{ No central to peripheral gradient } \\
\hline & $\begin{array}{l}\text { Left petrosal } \\
166 \mathrm{pg} / \mathrm{ml}\end{array}$ & \\
\hline & $\begin{array}{l}\text { Right petrosal } \\
92 \mathrm{pg} / \mathrm{ml}\end{array}$ & \\
\hline & peripheral $77 \mathrm{pg} / \mathrm{ml}$ & \\
\hline \multirow[t]{4}{*}{$\begin{array}{l}\text { IPSS (CRH } \\
\text { augmented) }\end{array}$} & $\begin{array}{l}\mathrm{ACTH} \text { values } \\
5 \text { mins post } \mathrm{CRH}\end{array}$ & \multirow[t]{2}{*}{$\begin{array}{l}\text { Marked central to peripheral } \\
\text { gradient (PPV } 98 \% \text { ) }\end{array}$} \\
\hline & $\begin{array}{l}\text { Left petrosal } \\
>2100 \mathrm{pg} / \mathrm{ml}\end{array}$ & \\
\hline & $\begin{array}{l}\text { Right petrosal } \\
271 \mathrm{pg} / \mathrm{ml}\end{array}$ & \multirow[t]{2}{*}{$\begin{array}{l}\text { Lateralising to left } \\
\text { (accuracy } 69 \% \text { ) }[28,29]\end{array}$} \\
\hline & $\begin{array}{l}\text { peripheral } \\
176 \mathrm{pg} / \mathrm{ml}\end{array}$ & \\
\hline
\end{tabular}

DST- Dexamethasone suppression test

UFC - Urinary free cortisol

$\mathrm{CRH}$ - Corticotropin-releasing hormone

ACTH- Adrenocorticotrophic hormone

IPSS - Inferior petrosal sinus sampling

ULN - Upper limit of normal

PPV-positive predictive value for diagnosis of pituitary-dependant Cushing's

syndrome (Cushing's disease)

expression throughout all of the resected material. There was no evidence of isolated focal ACTH immunostaining in the resected pituitary tissue. ACTH immunostaining would have been markedly suppressed in the non-adenomatous gland in the presence of an $\mathrm{ACTH}$-secreting pituitary adenoma if such an adenoma was present in the gland, but not in the laboratory specimen (a phenomenon which is recognised in some cases following successful neurosurgery for Cushing's disease). Also, reticulin staining demonstrated a normal pericellular reticulin pattern, as opposed to the pattern of reticulin disruption that would be expected if an adenoma were present [6]. Therefore, this extensive $\mathrm{ACTH}$ expression in the resected adenohypophysis tissue reflected diffuse corticotroph cell hyperplasia.

\section{Clinical course}

Six weeks post-operatively, the patient underwent a glucagon stimulation test, which showed severe growth hormone deficiency and persistent severe hypocortisolaemia. The patient was started on recombinant human growth hormone (GH) therapy. He later developed post-GH secondary hypothyroidism and was treated with L-thyroxine. One year later, he remained hypocortisolaemic, and reported excellent progress. His weight has declined from a peak of 97 to $63 \mathrm{~kg}$ and his height has increased from 147 to $152 \mathrm{~cm}$. His Cushingoid features have also markedly improved.

\section{Conclusion}

Pituitary dependent Cushing's syndrome is rare in the paediatric population and is invariably due to corticotroph adenomas (1). In the adult population, multifocal corticotroph hyperplasia has been shown to precede adenoma development [7], and even to co-exist with adenomas [8-10]. However, several paediatric series have been reported - the largest by far a 28 -year prospective study in the National Institutes of Health, describing 200 children [11], none of whom demonstrated evidence of corticotroph hyperplasia as the aetiology of their Cushing's disease. The other large case series are all considerably smaller by comparison, for example; a 15-year retrospective study from the Mayo Clinic reporting only 22 patients [12], 33 cases described in the southern United States [13], and 25 cases described in Britain [14]. However, none of the paediatric patients in these case series demonstrated corticotroph hyperplasia as the aetiology of their Cushing's disease. However, corticotroph hyperplasia as a cause of Cushing's disease in a paediatric patient was reported in a single case from Finland [15]. Surprisingly, and in sharp contrast with the American and British series, 3 of 15 patients in a Brazilian case series [16] were reported as having increased numbers of ACTH staining cells with no evidence of an adenoma but no detailed histology was presented (10).

While the absence of an adenoma from the surgical specimen following successful transsphenoidal surgery for Cushing's disease is sometimes seen [11], in this case, the normal adenohypophysis should show marked suppression of ACTH immunostaining due to negative feedback from the long standing hypercortisolaemia [17]. In our case, however, the resected adenohypophysis showed markedly widespread ACTH immunopositivity consistent with hyperplasia. In adults, corticotroph hyperplasia can very rarely be secondary to ectopic corticotropinreleasing hormone secretion [18]. In our case, however, the fact that the hyperplasia was focal, and that the patient went into remission following only partial resection of the pituitary makes secondary corticotroph hyperplasia very unlikely; ongoing close observation is, however, necessary. 


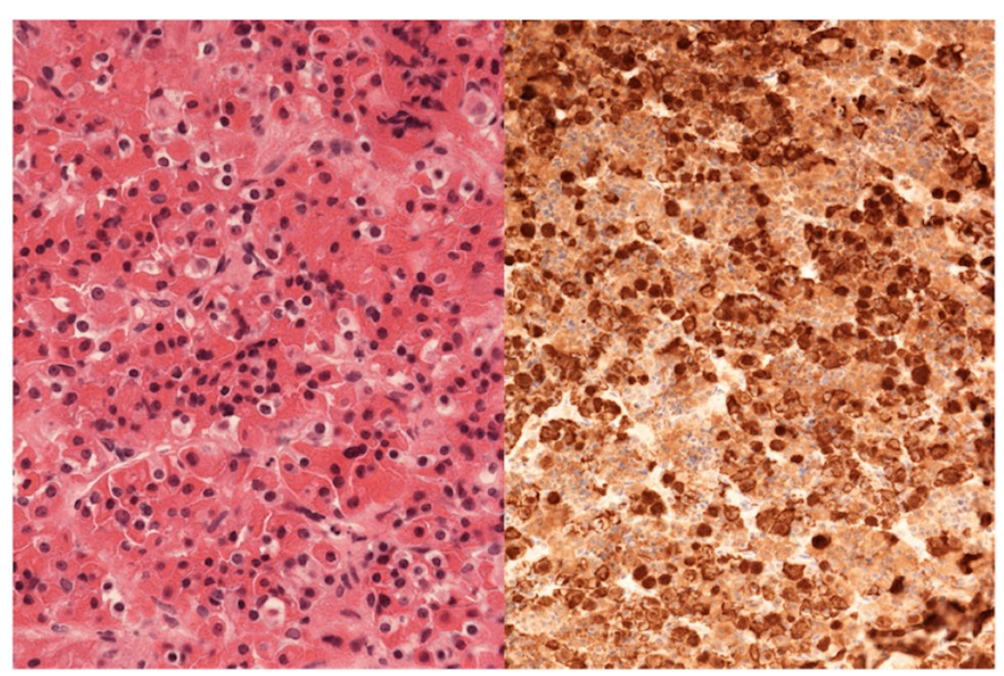

Fig 3 Resected adenohypophysis. Cells with eosinophilic cytoplasm and clear cytoplasm with occasional cells having basophilic cytoplasm are seen on the left. The specimen on the right shows extensive ACTH staining without evidence of focal suppression

Although cyclical hypercortisolism can be demonstrated in approximately $15 \%$ of adult patients with Cushing's disease, and perhaps up to $40 \%$ of adults with Cushing's syndrome [2, 19-21], it is much rarer in children, Only 2 cases were observed in a large case series of 59 paediatric patients with Cushing's syndrome [22], and only one case in a large series that included 17 paediatric patients [2]. There are only ten reports of cyclical cortisol hypersecretion in the paediatric population in the literature [3]. These are predominantly due to nodular adrenocortical disease [22-24], although pituitary adenoma [19], ectopic corticotropin secretion [22], and unknown aetiology [25] have all been described. This therefore represents a very rare case of cyclical Cushing's disease due to corticotroph hyperplasia in a paediatric patient. The demonstration of several late night salivary cortisol peaks and two normal troughs makes this a robust diagnosis of cyclicity.

Cushing's disease is associated with a high rate of relapse, particularly in children [12], but early surgical remission rates following transsphenoidal surgery are comparable to those in the adult population [26]. The finding of severe postoperative hypocortisolism in the postoperative period indicates a good longer-term prognosis [11] (positive predictive value of $96 \%$ for long-term remission in a paediatric population if postoperative morning cortisol $<28 \mathrm{nmol} / \mathrm{L}$ in one series). However, due to the cyclical nature of the original disease, close long-term follow-up, with repeated biochemical testing as well as clinical evaluation, will be essential for our patient. Most recently, the desmopressin test has been proposed as a useful predictor of recurrence of disease, either alone, or in combination with the dexamethasone test [27]. It is not, however, a well-established follow-up test for Cushing's disease in the paediatric population, and we therefore do not have data on this.

This case illustrates the capricious nature of Cushing's disease and demonstrates the necessity of both keeping a differential diagnosis in mind, and the utility of using different methods of assessing cortisol secretion in this diagnostically challenging condition.

\section{Consent}

Written informed consent was obtained from the patient and his legal guardian for publication of this case report and any accompanying images. A copy of the written consent is available for review by the Editor of this journal.

\section{Competing interests}

The authors declare that they have no competing interests.

\section{Authors' contributions}

EN treated the patient, gathered data and drafted the manuscript. SG treated the patient, gathered data and critically reviewed the manuscript. TB treated the patient, gathered data, and critically reviewed the manuscript. MF prepared, analysed, and interpreted the histopathological samples, and critically reviewed the manuscript. MJ treated the patient, carried out the surgery, gathered data, and critically reviewed the manuscript. CC treated the patient, gathered data, and critically reviewed the manuscript. AA treated the patient, conceptualized the case report, gathered data, and critically reviewed the manuscript. All authors approved the final version of the manuscript.

\section{Author details}

${ }^{1}$ Department of Endocrinology and Neurosurgery, Beaumont Hospital, Beaumont Road, Dublin 9, Ireland. ²Department of Neuropathology, Beaumont Hospital, Dublin, Ireland. ${ }^{3}$ Department of Neurosurgery, Beaumont Hospital, Dublin, Ireland. ${ }^{4}$ Department of Paediatric Endocrinology, Our Lady's Hospital for Sick Children, Dublin, Ireland.

Received: 2 February 2015 Accepted: 1 June 2015

Published online: 12 June 2015 


\section{References}

1. Savage MO, Storr HL, Chan LF, Grossman AB. Diagnosis and treatment of pediatric Cushing's disease. Pituitary. 2007;10(4):365-71.

2. Alexandraki Kl, Kaltsas GA, Isidori AM, Akker SA, Drake WM, Chew SL, et al. The prevalence and characteristic features of cyclicity and variability in Cushing's disease. Eur J Endocrinol. 2009;160(6):1011-8.

3. Meinardi JR, Wolffenbuttel BH, Dullaart RP. Cyclic Cushing's syndrome: a clinical challenge. Eur J Endocrinol. 2007;157(3):245-54.

4. Reimondo G, Paccotti P, Minetto M, Termine A, Stura G, Bergui M, et al. The corticotrophin-releasing hormone test is the most reliable noninvasive method to differentiate pituitary from ectopic ACTH secretion in Cushing's syndrome. Clin Endocrinol (Oxf). 2003;58(6):718-24.

5. Graham UM, Hunter SJ, McDonnell M, Mullan KR, Atkinson AB. A comparison of the use of urinary cortisol to creatinine ratios and nocturnal salivary cortisol in the evaluation of cyclicity in patients with Cushing's syndrome. J Clin Endocrinol Metab. 2013;98(1):E72-6.

6. Al-Brahim NY, Asa SL. My approach to pathology of the pituitary gland. J Clin Pathol. 2006;59(12):1245-53.

7. Saeger W. Concerning the article "Cushing's disease associated with both pituitary microadenoma and corticotroph hyperplasia". Exp Clin Endocrinol Diabetes. 2010;118(1):68.

8. Ludecke D, Kautzky R, Saeger W, Schrader D. Selective removal of hypersecreting pituitary adenomas? An analysis of endocrine function, operative and microscopical findings in 101 cases. Acta Neurochir (Wien). 1976;35(1-3):27-42.

9. Haap M, Gallwitz B, Meyermann R, Mittelbronn M. Cushing's disease associated with both pituitary microadenoma and corticotroph hyperplasia. Exp Clin Endocrinol Diabetes. 2009;117(6):289-93.

10. Meij BP, Lopes MB, Vance ML, Thorner MO, Laws Jr ER. Double pituitary lesions in three patients with Cushing's disease. Pituitary. 2000;3(3):159-68.

11. Lonser RR, Wind JJ, Nieman LK, Weil RJ, DeVroom HL, Oldfield EH. Outcome of surgical treatment of 200 children with Cushing's disease. J Clin Endocrinol Metab. 2013;98(3):892-901.

12. Leinung MC, Kane LA, Scheithauer BW, Carpenter PC, Laws Jr ER, Zimmerman D. Long term follow-up of transsphenoidal surgery for the treatment of Cushing's disease in childhood. J Clin Endocrinol Metab. 1995;80(8):2475-9.

13. Kanter AS, Diallo AO, Jane Jr JA, Sheehan JP, Asthagiri AR, Oskouian RJ, et al. Single-center experience with pediatric Cushing's disease. J Neurosurg. 2005:103(5 Suppl):413-20.

14. Joshi SM, Hewitt RJ, Storr HL, Rezajooi K, Ellamushi H, Grossman AB, et al. Cushing's disease in children and adolescents: 20 years of experience in a single neurosurgical center. Neurosurgery. 2005;57(2):281-5. discussion 281-285.

15. Mustila T, Keskinen P, Terho M, Huovinen S, Saha MT. Pediatric Cushing's disease due to pituitary hyperplasia. J Pediatr Endocrinol Metab. 2011;24(3-4):191-2.

16. Oliveira RS, Castro M, Antonini SR, Martinelli Jr CE, Moreira AC, Machado HR. Surgical management of pediatric Cushing's disease: an analysis of 15 consecutive cases at a specialized neurosurgical center. Arq Bras Endocrinol Metabol. 2010;54(1):17-23.

17. Saeger W, Ludecke DK, Buchfelder M, Fahlbusch R, Quabbe HJ, Petersenn S. Pathohistological classification of pituitary tumors: 10 years of experience with the German Pituitary Tumor Registry. Eur J Endocrinol. 2007;156(2):203-16.

18. Shahani S, Nudelman RJ, Nalini R, Kim HS, Samson SL. Ectopic corticotropinreleasing hormone $(\mathrm{CRH})$ syndrome from metastatic small cell carcinoma: a case report and review of the literature. Diagn Pathol. 2010;5:56.

19. Atkinson AB, Kennedy AL, Carson DJ, Hadden DR, Weaver JA, Sheridan B. Five cases of cyclical Cushing's syndrome. Br Med J (Clin Res Ed). 1985;291(6507):1453-7.

20. McCance DR, Gordon DS, Fannin TF, Hadden DR, Kennedy L, Sheridan B, et al. Assessment of endocrine function after transsphenoidal surgery for Cushing's disease. Clin Endocrinol (Oxf). 1993;38(1):79-86

21. Streeten DH, Anderson Jr GH, Dalakos T, Joachimpillai AD. Intermittent hypercortisolism: a disorder strikingly prevalent after hypophysial surgical procedures. Endocr Pract. 1997;3(3):123-9.

22. Magiakou MA, Mastorakos G, Oldfield EH, Gomez MT, Doppman JL, Cutler Jr GB, et al. Cushing's syndrome in children and adolescents. Presentation, diagnosis, and therapy. N Engl J Med. 1994;331(10):629-36.
23. Gunther DF, Bourdeau I, Matyakhina L, Cassarino D, Kleiner DE, Griffin K, et al. Cyclical Cushing syndrome presenting in infancy: an early form of primary pigmented nodular adrenocortical disease, or a new entity? J Clin Endocrinol Metab. 2004:89(7):3173-82.

24. Carson DJ, Sloan JM, Cleland J, Russell CF, Atkinson AB, Sheridan B. Cyclical Cushing's syndrome presenting as short stature in a boy with recurrent atrial myxomas and freckled skin pigmentation. Clin Endocrinol (Oxf). 1988;28(2):173-80.

25. Sato T, Funahashi T, Mukai M, Uchigata Y, Okuda N, Ichizen T. Periodic ACTH discharge. J Pediatr. 1980;97(2):221-5.

26. Storr HL, Alexandraki KI, Martin L, Isidori AM, Kaltsas GA, Monson JP, et al. Comparisons in the epidemiology, diagnostic features and cure rate by transsphenoidal surgery between paediatric and adult-onset Cushing's disease. Eur J Endocrinol. 2011;164(5):667-74

27. Le Marc'hadour P, Muller M, Albarel F, Coulon AL, Morange I, Martinie M, et al. Postoperative follow-up of Cushing's disease using cortisol, desmopressin and coupled dexamethasone-desmopressin tests: a head-to-head comparison. Clin Endocrinol (Oxf). 2015

28. Oldfield EH, Doppman JL, Nieman LK, Chrousos GP, Miller DL, Katz DA, et al. Petrosal sinus sampling with and without corticotropin-releasing hormone for the differential diagnosis of Cushing's syndrome. N Engl J Med. 1991:325(13):897-905.

29. Wind JJ, Lonser RR, Nieman LK, DeVroom HL, Chang R, Oldfield EH. The lateralization accuracy of inferior petrosal sinus sampling in 501 patients with Cushing's disease. J Clin Endocrinol Metab. 2013;98(6):2285-93.

\section{Submit your next manuscript to BioMed Central and take full advantage of:}

- Convenient online submission

- Thorough peer review

- No space constraints or color figure charges

- Immediate publication on acceptance

- Inclusion in PubMed, CAS, Scopus and Google Scholar

- Research which is freely available for redistribution 